\title{
Factors Affecting Biodiesel Production from Non-edible Vegetable Oil Via Base-catalyzed Transesterification Process: Synthesis
}

\author{
Degnechew Genene Demisu ${ }^{1,2}$ \\ ${ }^{1}$ School of Chemical and Bioengineering, Addis Ababa Institute of Technology, Addis Ababa University, Addis Ababa, Ethiopia \\ ${ }^{2}$ Bioenergy and Biochemical Research Division, Forest Products Innovation Research and Training Center, Ethiopian Environment and \\ Forest Research Institute (EEFRI), Addis Ababa, Ethiopia
}

\section{Email address: \\ dgeneneeth12@gmail.com}

\section{To cite this article:}

Degnechew Genene Demisu. Factors Affecting Biodiesel Production from Non-edible Vegetable Oil Via Base-catalyzed Transesterification Process: Synthesis. International Journal of Sustainable and Green Energy. Vol. 10, No. 3, 2021, pp. 85-91.

doi: $10.11648 /$ j.jirse.20211003.11

Received: March 26, 2021; Accepted: May 25 DD, 2021; Published: August 24, 2021

\begin{abstract}
Biodiesel (fatty acid alkyl ester) has received attention as greener, renewable, alternative source of energy; and its utilization as diesel fuel is becoming an auspicious source of energy that can substitute the non-renewable petroleum products. It can make significant contributions in diminishing the emission of harmful gaseous due to combustion of conventional fuel sources and hence, it is helpful to overcome challenges associated with energy crisis coupled with environmental pollution, climate change and global warming. Biodiesel is a carbon-neutral fuel source, biodegradable, non-toxic and can be synthesized from locally available non-edible vegetable oils via base-catalyzed transesterification process. This study presents the insight of operational variables or factors that influence the processing and yield of biodiesel (fatty acid alkyl ester) through transesterification of non-edible vegetable oils. These operational variables include, the amount of free fatty acid (FFA) in the non-edible vegetable oils, moisture in the oils, the amount and types of alcohol used, the non-edible vegetable oil to alcohol molar ratio, time allowed for the reaction, intensity of mixing, temperature, types of catalyzed used, concentration of catalyst and purity of reactants. The considered variables for preparation of biodiesel should be optimized to achieve the maximum possible conversion of reactants and thereby provide the highest possible yield of biodiesel product at the minimum possible operational cost.
\end{abstract}

Keywords: Biodiesel, Biofuel, Free Fatty Acid, Non-edible Vegetable Oil, Transesterification, Triglyceride

\section{Introduction}

Recently, the growth of demand in exploitation as well as usage of energy, the rise in oil price, the increase in fossil fuel consumption in industry and in transportation sectors, global warming due to the emissions of harmful gaseous into atmosphere, depletion of petroleum reserves, the increase in carbon dioxide $\left(\mathrm{CO}_{2}\right)$ level due to combustion of conventional fossil fuels have exacerbated the regional and global environment [1]. These environmental issues induce the emergence of alternative, renewable, biodegradable and environmentally friendly energy sources like biofuels (i.e. biodiesel) for transportation substituting the limited petroleum reserves; and thereby mitigating climate change while ensuring the sustainable development. Biofuel (i.e. Biodiesel) is considered as the promising renewable, ecofriendly and alternative fuel across the globe [2]. It has an immense potential for replacement of diesel fuel because it is relatively cleaner, greener, biodegradable and non-toxic energy source [3-5].

Biodiesel, a renewable energy source, is a fuel with chain fatty acid mono-alkyl esters synthesized from non-edible vegetable oils, waste cooking oil, microalgae and fats via transesterification of chemical reaction with appropriate alcohol and suitable catalysts [6-9]. Predominantly, biodiesel consists the fatty acid alkyl esters; and the corresponding alkyl end of fatty acid alkyl ester ranges from methyl $\left(\mathrm{CH}_{3}\right)$ to butyl $\left(\mathrm{C}_{4} \mathrm{H}_{9}\right)$ [10, 11]. Biodiesel exhibits good fuel 
characteristics and the viscosity of biodiesel is lower than its corresponding triglycerides; and hence, preferable or suitable for utilization in an engine without the requirement for alteration of the engine structure [12-14]. It consists 10-11\% $\mathrm{O}_{2}$ (oxygen) by weight, has no aromatic hydrocarbons and possesses a higher Cetane number $[15,16]$. Upon its combustion, these properties are helpful in minimizing emissions of greenhouse gases (GHG), particulate matters, carbon monoxide and unnecessary hydrocarbons into atmosphere [17-19]. Therefore, biodiesel offers a feasible solution to energy crisis, environmental degradation and the markedly diminishing conventional fossil fuels.

Availability of wide range of biodiesel production feedstocks or raw materials such as vegetable oils, fats derived from animal tissue and recycled waste cooking oil across the globe has been the main factor that forces researchers for further investigation in biofuel industries [20]. Nonetheless, the utilization of fats obtained from animals and edible oils for the synthesis of the biofuel induces the dispute of food supply versus fuel competitions in the long run [2124]. Thus, the exploitation of oils extracted from the nonedible vegetables to prepare and use the fuel (i.e. biodiesel) is becoming a predominant feedstock while meeting the international fuel standards. The present study aims at providing the insight of factors affecting biodiesel synthesis from non-edible vegetable oil via base catalyzed transesterification mechanism.

\section{The Transesterification Reaction Catalyzed by Base}

Biodiesel can be synthesized in a number of methods, including thermal cracking (pyrolysis) [25], oil dilution or blending [26], micro-emulsion [27], and via base-catalyzed transesterification process [28]. Among these, the transesterification reaction catalyzed by base is the most convenient way for synthesizing biodiesel [29]. The transesterification process involves the organic reaction between vegetable oils and alcohols, usually $\mathrm{CH}_{3} \mathrm{OH}$ (methanol) and $\mathrm{C}_{2} \mathrm{H}_{5} \mathrm{OH}$ (ethanol) using appropriate catalysts, such as heterogenous base catalysts [30-34], homogeneous base catalysts [35, 36], acid catalysts [37, 38] and bio-catalysts $[39,40]$ or without the requirement of catalyst [41]. Moreover, the base-catalyzed transesterification reaction is a step-wise stripping of glycerin from the fatty acids of the considered non-edible vegetable oil with proper base catalysts [42]; and thereby substituting it with anhydrous alcohols (i.e. methanol) and hence, producing the desired product (i.e. Biodiesel) and the by-product (i.e. glycerol). This process is also affected by variations in operation parameters like types of alcohol, molar ratio of vegetable oil to alcohol, mixing intensity, temperature, catalyst concentration as well as oil moisture content [43]. The stoichiometric chemical reaction of transesterification process can be provided as follow:

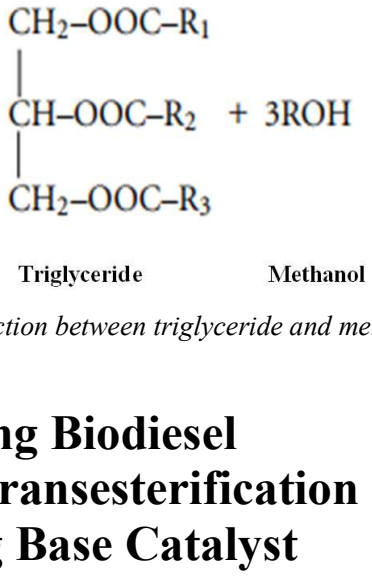

Synthesis of biodiesel through base-catalyzed transesterification process is influenced by diverse operational variables, including: amount FFA content in the feedstock [45], moisture in the oil [28], alcohol employed [46], Oil to alcohol molar ratio [47], time allowed for the reaction [48], mixing intensity [49], temperature [50], catalyst employed [42] and purity of reactants [12]. Hence, proper control and manipulation of these operational variables will improve the yield and characteristics of biodiesel.

\subsection{Amount of FFA in the Oil}

Transesterification reaction won't take place when percentage of FFA in the oil is greater than three percent [51].
Instead, high amount of FFA in the oil induces the saponification reaction (i.e. formation of water and soap) thereby diminishing the effectiveness and efficiency of catalyst, forming gel, increasing biodiesel viscosity and making glycerol separation cumbersome. Therefore, the problem with transesterification of non-edible vegetable oil of higher FFA (\%) can be solved by employing two-step transesterification; firstly, a homogeneous acid pretreatment of the oil [52-55], conducting esterification reaction (i.e. until FFA is less than $0.5 \%$ ) to produce ester. Secondly, a transesterification process catalyzed with base must be employed; and thereby completing the process [56-59]. Nonedible oil to be trans-esterified must be subjected to titration while employing the phenolphthalein indicator to measure the amount of selected catalysts for the reaction [60].

\subsection{Oil Moisture Content}

The water content in the non-edible vegetable oil highly affects the base-catalyzed transesterification mechanisms as 
the moisture in oil induces and accelerates the hydrolysis of ester with concomitant saponification reaction [28, 61]; and hence, it diminishes the formation of ester [61]. The moisture content of non-edible oil is more critical issue for esterification reaction catalyzed by acid than the basecatalyzed transesterification reaction. Moreover, it is formed as side product of acid catalyzed esterification mechanism (i.e. during conversion of free fatty acid into ester) [62]. Preheating of oil at $120^{\circ} \mathrm{C}$ favors the removal of water content before dispatch [63] and then, the oil is subjected to cooling to $60^{\circ} \mathrm{C}$ [64]. The moisture presented in the final product (i.e. Biodiesel) can be removed by using anhydrous magnesium sulfate- $\mathrm{MgSO}_{4}$ [65] and anhydrous sodium sulfate- $\mathrm{Na}_{2} \mathrm{SO}_{4}$ [51] while avoiding the backward reaction and increasing the biodiesel yield. Thus, to get about ninety percent yield of biodiesel, moisture content of the oil must be less than $0.5 \%$ [38].

\subsection{Type of Alcohol Employed and Oil to Alcohol Molar Ratio}

The selection of alcohol(s) for the base-catalyzed transesterification reaction depends upon their effectiveness or operational performance and their respective cost [46]. The transesterification mechanism necessitated the applications of lower alcohols, like methanol $\left(\mathrm{CH}_{3} \mathrm{OH}\right)$, ethanol $\left(\mathrm{C}_{2} \mathrm{H}_{5} \mathrm{OH}\right)$ and butanol $\left(\mathrm{C}_{4} \mathrm{H}_{9} \mathrm{OH}\right)$. Among these, methanol is a predominantly utilized alcohol for transesterification reaction process [48, 66-69] and methanol is more available and substantially cheaper in price than ethanol; and hence, the corresponding biodiesel derived from methanol is more preponderating commercial product than biodiesel derived from other alcohols [70]. Moreover, methanol is preferable to ethanol because it do possess lower boiling point than ethanol and hence, the recovery of unreacted alcohols from the downstream is relatively easier [71]. On the other hand, when the isopropanol or ethanol is employed in transesterification reaction, it exhibits formation of azeotrope with molecules of water; and thereby causing the alcohol-water separation cumbersome in the distiller [54].

During the base-catalyzed transesterification reaction, fatty acid triglyceride of one mole reacts with three mole of alcohol (i.e. usually methanol) to produce three mole of alkyl (i.e. methyl) ester as well as one mole of tri-hydroxy alcohol (i.e. glycerol) [72]. With this regard, the oil to alcohol molar ratio has significant effect on the rate of conversion of triglyceride into the alkyl ester (Biodiesel) [73]. According to the principle of Le Chatelier's, the gradual rise in concentration of reactants enhances the product formation rate and vice-versa. Hence, increasing the concentration of alcohol enhances the biodiesel formation rate [55]. A maximum triglyceride conversion into alky ester (Biodiesel) takes place at 1:6 oil to alcohol molar ratio [47, 67, 74-77]. The efficiency of reactant conversion remains constant upon further increasing molar ratio of oil to alcohol. Nonetheless, higher molar ratio of oil to alcohol beyond optimum point makes alcohol recovery cumbersome [78].

\subsection{Reaction Time}

To diminish biodiesel synthesis operational cost via base-catalyzed transesterification of triglyceride in the non-edible vegetable oil, the optimum reaction time should be employed. The best conversion of reactants and completion of the chemical reaction relies on reaction time and it has been found that 60 minute is the optimum reaction time that provides the best biodiesel yield $[47,48$, 76]. About $99 \%$ of biodiesel can be obtained when the transesterification reaction is conducted for longer time. However, extra reaction time beyond the optimum favors hydrolysis of fatty acid alkyl ester (biodiesel) or the backward reaction is promoted; and hence, diminishes the product yield [28, 36, 79]. Besides, longer residence time of reaction reduces the specific gravity of the desired product exponentially and ceases with asymptotic values relatively with provided time [48].

\subsection{Intensity of Mixing}

The base-catalyzed transesterification reaction is a slow process due to the immiscibility of alcohols and oils; and due to the occurrence of the chemical reaction in the interfacial surface between fatty acid triglycerides and alcohols [80]. Inadequate mass transfer between triglycerides and alcohol interface is slow and critical step and hence, it is considered as a rate limiting step for the transesterification reaction [49]. Thus, agitation is necessitated to enhance the contact surface area between the non-miscible phases [81]; and thereby achieving the completion of the reaction process while enhancing the yield of the desired product [49]. Moreover, mixing favors the diffusion of alcohol molecules into triglycerides and rises the interfacial collision between particles. The higher the mixing intensity favors the shorter reaction time and increase the rate of conversion of reactants [82]. Nevertheless, beyond the considered speed of agitator, the rise in the biodiesel yield will be insignificant. Hence, optimum agitator speed should be employed for a variety of biodiesel feedstocks depending upon the respective physical properties of reactants. In this regard, it has been demonstrated that the higher conversion of reactants was observed by adjusting the speed of agitator between 100 and 200 revolutions per minute [83].

\subsection{Reaction Temperature}

A base-catalyzed transesterification reaction is affected by reaction temperature [84]. Increasing the temperature of the reaction increases reaction rate and thereby enhances yield of biodiesel $[50,72]$. In addition, the higher temperature tends to minimize the required time to achieve maximum possible conversion of reactants [70]. However, the reaction temperature should be kept below alcohol's boiling point because increasing temperature beyond alcohol's boiling point induces vaporization of alcohol and bubble formation that suppress the transesterification mechanism $[52,76]$. On the other hand, keeping temperature far below alcohol's boiling point increases the fatty acid alkyl ester (biodiesel) 
viscosity [85]. Thus, the operation should be conducted at optimum temperature of reaction between $63-68^{\circ} \mathrm{C}$ so as to provide maximum yield of the desired product [54].

\subsection{Catalyst Type and Concentration}

Catalysts (i.e. chemical and biological) are substances that promote chemical reaction rate by diminishing primary activation energy. During transesterification reaction of nonedible vegetable oil and alcohol, catalysts play significant roles in the process [86]. Moreover, a number of catalysts (i.e. heterogeneous, homogeneous and enzymatic catalysts) can be utilized for biodiesel synthesis [87]. For instances, the homogeneous alkali catalysts and their respective methoxides are preponderantly employed in biodiesel processing industries because of their availability, low cost, ease of handling and transportation [46-48, 67, 75, 78]. The use of potassium methoxide (base catalyst) in the transesterification reaction, with concentrated sulfuric acid $\left(\mathrm{H}_{2} \mathrm{SO}_{4}\right)$ catalyst as pretreatment or esterification reaction $[42,88]$, provides the maximum possible yield of biodiesel [48]. Nonetheless, one of the major drawbacks of using homogeneous base catalyst is its soap formation and the difficulty of its recovery from the end product [88]. In order to overcome such challenges, heterogeneous base catalyst has been considered as it withstand the effect of FFA and moisture in the oil [52]. Hence, the use of several heterogeneous catalysts (i.e. solid acid and alkali catalyst) is helpful to enhance rate of transesterification mechanism. A solid acid catalyst can be employed for oil of high FFA as it exhibits higher stability, eliminates problems of corrosion, replaces liquid acids and no deactivation of the catalyst surface [72, 89] relatively when compared with solid heterogeneous base catalyst [38].

The concentration of catalyst to be employed is related to the amount of FFA in non-edible oil. Oil of higher FFA necessitated addition of more acidic and alkaline catalysts respectively to inhibit the deactivation of catalyst and to compensate the acidity of the oil [42]. However, the addition of extra catalyst induces the formation of gel and emulsion thereby raising the viscosity of fatty acid alkyl ester (biodiesel) which in turn impede glycerin separation from the biodiesel $[67,90]$. Hence, the utilization of optimum catalyst concentration (1\%wt.) should be considered to enhance reactant's conversion rate thereby maximizing the yield [72].

\section{Conclusion}

Environmental degradation, air pollution due to the release of harmful gaseous emissions, growth of demand in exploitation and usage of energy globally along with the rapidly diminishing petroleum products (i.e. Automotive Diesel Oil-ADO, kerosene, Motor Gas Regular-MGR) necessitated the search for alternative, renewable and sustainable fuel sources for the replacement of conventional fossil fuel (i.e. petroleum). In this respect, biodiesel is considered as greener, renewable, alternative source of energy, environmentally benign and synthesized from locally available biological feedstocks. It can be produced via base-catalyzed transesterification reaction, dilution, pyrolysis (thermal cracking) and microemulsion. It's production process (i.e. via base-catalyzed transesterification mechanism) necessitated adequate knowledge, good technical skills and deep understanding of the nature of operational variables, including: purity of reactants, fatty acid content of non-edible vegetable oils, oil moisture contents, types and concentration of catalyst employed, temperature, agitation speed, reaction time and molar ratio of oil to alcohol. Therefore, it is recommended that the considered operational variables should be controlled accordingly and optimized carefully while obtaining the best yield of the desired product and realizing viability of the production process.

\section{References}

[1] Chouhan, A. S., Sarma, A. K., (2011). Modern heterogeneous catalysts for biodiesel production: A comprehensive review. Renewable and Sustainable Energy Reviews, 15, 4378-4399.

[2] Chand, N., (2002). Plant oils- Fuel of the future. J. Sci. Ind. Res. 61: 7-16.

[3] Asif, S., Ahmad, M., Bokhari, A., Chuah, L. F., Klemeš, J. J., Akbar, M. M., Sultana, S., Yusup, S., (2017). Methyl ester synthesis of Pistacia khinjuk seed oil by ultrasonic-assisted cavitation system. Ind. Crops Prod. 108: 336-347. https:// doi.org/10.1016/j.indcrop.2017.06.046.

[4] Chuah, L., Awais, B., (2017). A review of cleaner intensification technologies in biodiesel production. Clean. Prod. 146: 181-193. https://doi.org/ 10.1016/j.jclepro.2016.05.017.

[5] Ranganathan, S. V., Narasimhan, S. L., and Muthukumar, K., (2008). Bioresources Technology, 99, 3975-3881.

[6] Sarin, (2012). Biodiesel Production (RSC Publishing, Cambridge, 2012), pp. 2.

[7] Zininga, J. T., Puri, A. K., Govender, A., Singh, S., Permaul, K., (2019). Concomitant production of chitosan and lipids from a newly isolated Mucor circinelloides ZSKP for biodiesel production. Bioresour Technol. 272: 545-551.

[8] Guan, G., Kusakabe, K., Sakurai, N., Momiyama, K, (2009). Transesterification of vegetable oil to biodiesel fuel using acid catalysts in the presence of dimethyl ether. Fuel. 88: 81-86.

[9] Wang, Y., Ou, S., Liu, P., Xue, F., and Tang, S., (2006). Comparison of two different processes to synthesize biodiesel by waste cooking oil. Journal of Molecular Catalysis A. Chemical, 252, 107-112.

[10] EN-14214, (2003). Automotive fuels-fatty acid methyl esters (FAME) for diesel engines: requirements and test methods. https://www.aascarburants.com/assets/fles/pdf/BiodieselEN14214.pdf.

[11] Lepper, H., and Friesenhagen, L., (1984). Process for the production of fatty acid alkyl esters, CA1261870A.

[12] Sergejus, L., and Andrius, V., (2006). Research into the application of biodiesel in the transport sector of lithuania. Transport. 21 (2): 80-87. 
[13] Akhabue, C. E., and Okwundu, O. S., (2017). Monitoring the transesterification reaction of castor oil and methanol by ultraviolet visible spectroscopy. Biofuels, 1-8. https://doi.org/10.1080/17597269.2017.1338128.

[14] Kuan, I. C., Kao, W. C., Chen, C. L., Yu, C. Y., (2018). Microbial biodiesel production by direct transesterification of rhodotorula glutinis biomass. Energies. https://doi.org/10.3390/en11051036.

[15] Math, M. C., Kumar, S. P., and Chetty, S. V., (2010). Technologies for biodiesel production from used cooking oilA review. Energy for Sustainable Development, 14, 339-345.

[16] Lin, Y. H., Luo, J. J., Hwangb, S. J., Liau, P. R., Lu, W. J., Lee, H. T., (2011). The influence of free fatty acid intermediate on biodiesel production from soybean oil by whole cell biocatalyst. Biomass and bionergy, 35, 2217-2223.

[17] Chang, D. Y. Z., and Gerpen, V. J. H., (1997). Fuel properties and engine performance for biodiesel prepared from modified feedstocks. Warrendale, PA: Society for Automotive Engineering, Paper No. 971684.

[18] Chang, D. Y. Z., Gerpen V. J. H., Lee, I., Johnson, L. A., Hammond, E. G., and Marley, S. J., (1996). Fuel properties and emissions of soybean oil esters as diesel fuel. J Am Oil Chem Soc. 73 (11): 1549-1555.

[19] Graboski, M. S., McCormick, R. L., (1998). Combustion of fat and vegetable oil derived fuels in diesel engines. Prog Energy Combust Sci. 24: 125-164.

[20] Adewale, P., Dumont, M. J., Ngadi, M., (2015). Recent trends of biodiesel production from animal fat wastes and associated production techniques. Renewable Sustainable Energy Rev. 45: 574-588. https://doi.org/10.1016/j.rser.2015.02.039.

[21] Pimentel, D., Marklein, A., Toth, M. A., Karpoff, M. N., Paul, G. S., McCormack, R., Kyriazis, J., and Krueger, T., (2009). Food versus biofuels: Environmental and economic costs. Hum. Eco. 37 (1): 1-12.

[22] Srinivasan, S., (2009). The food versus fuel debate: A nuanced view of incentive structures. Renewable Energy, 34 (4), 950954

[23] Lam, M. K., Tan, K. T., Lee, K. T., Mohamed, A. R., (2009). Malaysian palm oil: Surviving the food versus fuel debate for a sustainable future. Renew. Sust. Energ. Rev. 13 (6-7): 1456-1464.

[24] Metzger, J. O., (2009). Fats and oils as renewable feedstock for chemistry. Eur. J. Lipid Sci. Tech. 111 (9): 865-876.

[25] Sani, Y. M., Daud, W. M., and Abdul, R. A., (2013). Biodiesel feedstock and production technologies: successes, challenges and prospects.

[26] Shikha, K., and Chauhan, Y. R., (2012). Biodiesel production from non-edible-oils: a review. Journal of Chemical and Pharmaceutical Research, 4 (9), 4219-4230.

[27] Rajalingam, A., Jani1, S. P., Senthil K. A., and Adam K. M., (2016). Production methods of biodiesel. Journal of Chemical and Pharmaceutical Research, 8 (3), 170-173.

[28] Leung, D. Y. C., and Guo, Y., (2006). Transesterification of neat and used frying oil: Optimization for biodiesel production. Fuel Process Tech. 87 (10): 883-890.

[29] Kirubakaran, M., and Selvan, V., (2018). A comprehensive review of low cost biodiesel production from waste chicken fat. Renew Sustain Energy Rev. 82: 390-401.

[30] Xie, W., Hu, L., and Yang, X., (2015a). Basic ionic liquid supported on mesoporous SBA-15 silica as an efficient heterogeneous catalyst for biodiesel production. Ind. Eng. Chem. Res. 54: 1505-1512.

[31] Xie, W., Yang, X., and Fan, M., (2015b). Novel solid base catalyst for biodiesel production: mesoporous SBA-15 silica immobilized with 1, 3-dicyclohexyl-2- octylguanidine. Renew. Energy. 80: 230-237. https://doi.org/10.1016/j.renene. 2015.02.014.

[32] Xie, W., and Fan, M., 2014. Biodiesel production by transesterification using tetraalkylammonium hydroxides immobilized onto SBA-15 as a solid catalyst. Chem. Eng. J. 239: 60-67. https://doi.org/10.1016/j.cej.2013.11.009.

[33] Xie, W., and Wang, J., (2014). Enzymatic production of biodiesel from soybean oil by using immobilized lipase on $\mathrm{Fe}_{3} \mathrm{O}_{4} /$ Poly (styrene-methacrylic acid) magnetic microsphere as a biocatalyst. Energy Fuels, 28, 2624-2631.

[34] Xie, W., and Zhao, L., (2013). Production of biodiesel by transesterification of soybean oil using calcium supported tin oxides as heterogeneous catalysts. Energy Convers. Manag. 76: 55-62. https://doi.org/10.1016/j.enconman.2013.07.027.

[35] Atadashi, I. M., Aroua, M. K., Abdul, A. A., Sulaiman, N. M., (2013). The effects of catalysts in biodiesel production: a review. J. Ind. Eng. Chem. 19: 14-26. https://doi.org/10.1016/j.jiec.2012.07.009.

[36] Hossain, A. B., Boyce, A. N., Salleh, A., Chandran, S., (20100. Impacts of alcohol type, ratio and stirring time on the biodiesel production from waste canola oil. Afr. J. Agric. Res. 5: 1851-1859. https://doi.org/10.5897/AJAR09.135.

[37] Demirbas, A., (2008) Comparison of transesterification methods for production of biodiesel from vegetable oils and fats. Energy Convers Manag. 49: 125-130.

[38] Lotero, E., Liu, Y., Lopez, D. E., Suwannakarn, K., Bruce, D. A., and Goodwin, J. G., (2005). "Synthesis of biodiesel via acid catalysis," Industrial and Engineering Chemistry Research, 44 (14), 5353-5363.

[39] Gog, A., Roman, M., Toşa, M., Paizs, C., and Irimie, F. D., (2012). Biodiesel production using enzymatic transesterification-current state and perspectives. Renew Energy. 39: 10-16.

[40] Sarno, M., and Iuliano, M., (2018). Active biocatalyst for biodiesel production from spent coffee ground. Bioresour Technol. 266: 431-438.

[41] Iijima, W., Kobayashi, Y., and Taniwaki, K., (2006). Process for non-catalytically producing biodiesel fuel without yielding by-product, US20060288636A1.

[42] Freedman, B., Pryde, E. H., and Mounts, T. L., (1984). "Variables affecting the yields of fatty esters from transesterifed vegetable oils. Journal of the American Oil Chemists'Society, 61 (10), 1638-1643.

[43] Stamenkovic, O. S., Lazic, M. L., Todorovic, Z. B., Veljkovic, V. B., Skala, D. U., (2007). The effect of agitation intensity on alkali-catalyzed methanolysis of sunflower oil. Bioresour. Tech. 98 (14): 2688-2699. 
[44] Sanli, H., and Canakci, M., (2008). "Effects of different alcohol and catalyst usage on biodiesel production from different vegetable oils." Energy and Fuels, 22 (4), 27132719 .

[45] Kulkarni, M. G., and Dalai, A. K., (2006). Waste cooking oilan economical source for biodiesel: A review. Ind. Eng. Chem. Res. 45 (9): 2901-2913.

[46] Encinar, J. M., Juan, F., Gonzalez, J. F., and RodriguezReinares, A., (2007). Ethanolysis of used frying oils: Biodiesel preparation and Characterization. Fuel Process. Tech. 88 (5): 513-522.

[47] Tomasevic, A. V., Siler-Marinkovic, S. S., (2003). Methanolysis of used frying oil. Fuel Process Tech. 81 (1): $1-6$.

[48] Refaat, A. A., Attia, N. K., Sibak, H. A., El Sheltawy, S. T., and El Diwani, G. I., (2008a). Production optimization and quality assessment of biodiesel from waste vegetable oil. Int. J. Environ. Sci. Tech. 5 (1): 75-82.

[49] Canakci M., and Van Gerpen, J., (2003). "A pilot plant to produce biodiesel from high free fatty acid feedstocks," Transactions of the American Society of Agricultural Engineers, 46 (4), 945-954.

[50] Colucci, J., Borrero, E. E., and Alape, F., (2005). Biodiesel from an alkaline transesterification reaction of soybean oil using ultrasonic mixing, Journal of the American Oil Chemists Society, 82, 525-530.

[51] Ahmad, M., Ahmed, S., Hassan, F. U., Arshad, M., Khan, M. A., Zafar, M., and Sultana, S., (2010). "Base catalyzed transesterification of sunflower oil biodiesel," African Journal of Biotechnology, 9 (50), 8630-8635.

[52] Li, S., Wang, Y., Dong, S., Chen, Y., Cao, F., Chai, F., and Wang X., (2009). "Biodiesel production from Eruca Sativa Gars vegetable oil and motor, emissions properties," Renewable Energy, 34 (7), 1871-1876.

[53] El Sherbiny, S. A., Refaat, A. A., and El Sheltawy, S. T., (2010). "Production of biodiesel using the microwave technique," Journal of Advanced Research, 1 (4), 309-314.

[54] Van Gerpen, J., (2005). "Biodiesel processing and production," Fuel Processing Technology, 86 (10), 1097-1107.

[55] Knothe, G., and Steidley, K. R., (2009). "A comparison of used cooking oils: a very heterogeneous feedstock for biodiesel," Bio-resource Technology, 100 (23) vol. 100, 57965801 .

[56] Corro, G., Tellez, N., Ayala, E., and Marinez-Ayala, A., (2010). "Two-step biodiesel production from Jatropha curcas crude oil using $\mathrm{SiO}_{2} \mathrm{HF}$ solid catalyst for FFA esterification step," Fuel, 89 (10), 2815-2821.

[57] Muthu, H., Selvabala, V. S., Varathachary, T. K., Selvaraj, D. K., Nandagopal, J., and Subramanian, S., (2010). "Synthesis of biodiesel from neem oil using sulfated zirconia via transesterification," Brazilian Journal of Chemical Engineering, 27 (4), 601-608.

[58] Mathiyazhagan, M., Ganapathi, A., Jaganath, B., Renganayaki, N., and Sasireka, N., (2011). "Production of biodiesel from non-edible plant oils having high FFA content," International Journal of Chemical and Environmental Engineering, 2 (2), 119-122.
[59] Chen, L., Yin, P., Liu, X., Yang, L., Yu, Z., Guo, X., and Xin, $X .$, (2011). "Biodiesel production over copper vanadium phosphate," Energy, 36 (1), 175-180.

[60] Sudhir, C. V., Sharma, N. Y., Mohanan, P., (2007). Potential of waste cooking oil as biodiesel feedstock. Emirates J. Eng. Res. 12 (3): 69-75.

[61] Arun, N., Sampath, M., Siddharth, S., and Prasaanth, R. A., (2011). "Experimental Studies of base catalyzed transesterifcation of karanja oil," Journal of Energy and Environment, 2 (2), 351-356.

[62] Canakci, M., (2007). "The potential of restaurant waste lipids as biodiesel feedstocks," Bio-resource Technology, 98 (1), 183-190.

[63] Ahmad, M., Rashid, S., Khan, M. A., Zafar, M., Sultana, S., and Gulzar, S., (2009). "Optimization of base catalyzed transesterification of peanut oil biodiesel," African Journal of Biotechnology, 8 (3), 441-446.

[64] Chen, K. S., Lin, Y. C., Hsu, K. H., and Wang, H. K., (2012). "Improving biodiesel yields from waste cooking oil by using sodium methoxide and a microwave heating system," Energy, $38,151-156$.

[65] Hossain, A. B., and Boyce, A. N., (2009). "Biodiesel production from waste sunflower cooking oil as an environmental recycling process and renewable energy," Bulgarian Journal of Agricultural Science, 15 (4), 312-317.

[66] Alcantara, R., Amores, J., Canoira, L., Fidalgo, E., Franco, M. J., and Navarro, A., (2000). Catalytic production of biodiesel from soy-bean oil, used frying oil and tallow. Biomass Bioenerg. 18 (6): 515-527.

[67] Encinar, J. M., Gonzalez, J. F., and Rodriguez-Reinares, A., (2005). Biodiesel from used frying oil. Variables affecting the yields and characteristics of the biodiesel. Ind. Eng. Chem. Res. 44 (15): 5491-5499.

[68] Felizardo, P., Correia, M. J., Raposo, I., Mendes, J. F., Berkemeier, R., and Bordado J. M., (2006). Production of biodiesel from waste frying oils. Waste Manage. 26 (5): 487494.

[69] Yuan, X., Liu, J., Zeng, G., Shi, J., Tong, J., and Huang, G., (2008). Optimization of conversion of waste rapeseed oil with high FFA to biodiesel using response surface methodology. Renew. Energ. 33 (7): 1678-1684.

[70] Pinto, A. C., Guarieiro, L. N., Rezende, M. J., Ribeiro, N. M., Torres, E. A., Lopes, W. A., Pereira, P. A., and Andrade, J. B., (2005). Biodiesel: An overview. J. Brazil. Chem. Soc. 16 (6B): 1313-1330.

[71] Zhou, W., and Boocock, D. G. B., (2006). Phase behavior of the base-catalyzed transesterification of soybean oil. J. Am. Oil Chem. Soc. 83 (12): 1041-1045.

[72] Highina, B. K., Bugaje, I. M., and Umar, B., (2011). "Biodiesel production from Jatropha caucus oil in a batch reactor using zinc oxide as catalyst," Journal of Petroleum Technology and Alternative Fuels, 2 (9), 146-149.

[73] Noshadi, I., Amin, N. A. S., and Parnas, R. S., (2012). "Continuous production of biodiesel from waste cooking oil in a reactive distillation column catalyzed by solid heteropolyacid: optimization using response surface methodology (RSM)," Fuel, 94, 156-164. 
[74] Saifuddin, N., and Chua, K. H., (2004). Production of ethyl ester (Biodiesel) from used frying oil: Optimization of transesterification process using microwave irradiation. Malays. J. Chem. 6 (1), 77- 82.

[75] Gupta, A., Sharma, S. K., and Pal Toor, A., (2007). Production of biodiesel from waste soybean oil. J. Petrotech Soc. 4 (1): 40-45.

[76] Meng, X., Chen, G., and Wang, Y., (2008). Biodiesel production from waste cooking oil via alkali catalyst and its engine test. Fuel Process Tech. 89 (9): 851-857.

[77] Refaat, A. A., El Sheltawy, S. T., and Sadek, K. U., (2008b). Optimum reaction time, performance and exhaust emissions of biodiesel produced by microwave irradiation. Int. J. Environ. Sci. Tech. 5 (3): 315-322.

[78] Demirbas, A., (2009). Biodiesel from waste cooking oil via base-catalytic and supercritical methanol transesterification. Energ. Convers. Manage. 50 (4): 923-927.

[79] Refaat, A., (2010). "Different techniques for the production of biodiesel from waste vegetable oil," International Journal of Environmental Science and Technology, 7 (1) vol. 7, 183-213.

[80] Noureddini, H., and Zhu, D., (1997). Kinetics of transesterification of soybean oil. J. Am. Oil Chem. Soc. 74 (11): 1457-1463.

[81] Singh, A. K., and Fernando, S. D., (2006). Catalyzed fasttransesterification of soybean oil using ultra-sonication. American Society of Agricultural Engineers, ASAE Annual Meeting, Portland, Oregon, USA.

[82] Adeyemi, N. A., Mohiuddin, A., and Jameel, T., (2011). "Waste cooking oil transesterification: influence of impeller type, temperature, speed and bottom clearance on FAME yield," African Journal of Biotechnology, 10 (44), 8914-8929.

[83] Kumari, A., Mahapatra, P., Garlapati V. K., and Banerjee R., (2009). "Enzymatic transesterification of Jatropha oil," Biotechnology for Biofuels, vol. 2.

[84] Darnoko, D., and Cheryan M., "Kinetics of palm oil transesterification in a batch reactor," Journal of the American Oil Chemists'Society, 77 (12), 1263-1267.

[85] Kapilakarn, K., and Peugtong, A., (2007). "A comparison of costs of biodiesel production from transesterification," International Energy Journal, 8 (1), 1-6.

[86] Issariyakul, T., and Dalai, A. K., (2014). Biodiesel from vegetable oils. Renewable and Sustainable Energy Reviews, 31: 446-471.

[87] Vicente, G., Martınez, M., and Araci, J., (2004). "Integrated biodiesel production: a comparison of different homogeneous catalysts systems," Bioresource Technology, 92, 297-305.

[88] Freedman, B., Butterfield, R. O., Pryde, E. H., (1986). Transesterification kinetics of soybean oil. J. Am. Oil Chem. Soc. 63 (10): 1375-1380.

[89] Cao, F., Chen, Y., Zhai, F., Li, J., Wang, J., Wang, X., Wang, S., Zhu, W., (2008). Biodiesel production from high acid value waste frying oil catalyzed by superacid heteropolyacid. Biotech. Bioengin. 101 (1): 93-100.

[90] Kiakalaieh, A. T., Amin, N. A. S., Zarei A., and Noshadi, I., (2013). "Transesterifcation of waste cooking oil by heteropoly acid (HPA) catalyst: optimization and kinetic model," Applied Energy, 102, 283-292. 